\title{
Magnetic Resonance Imaging (MRI) Contrast Agents for Tumor Diagnosis
}

\author{
Weiren Cheng ${ }^{1,2}$, Yuan Ping ${ }^{1}$, Yong Zhang ${ }^{2}$, Kai- Hsiang Chuang ${ }^{3}$ and Ye Liu ${ }^{1 *}$ \\ ${ }^{1}$ Institute of Materials Research and Engineering, ${ }^{3}$ Singapore Bioimaging Consortium \\ (SBIC), A*STAR (Agency for Science, Technology and Research), Singapore \\ ${ }^{2}$ Division of Bioengineering, Faculty of Engineering, National University of \\ Singapore, Singapore
}

Submitted August 2012. Accepted for publication November 2012.

\begin{abstract}
This review focuses on MRI contrast agents for tumor diagnosis. Several types of low molecular weight $\mathrm{Gd}^{3+}$-based complexes and dextran-coated superparamagnetic iron oxide (SPIO) nanoparticles have been used for clinical tumor diagnosis as longitudinal relaxation time $\left(T_{1}\right)$ and transverse relaxation time $\left(T_{2}\right)$ MRI contrast agents, respectively. To further improve the sensitivity of MRI, new types of chelates for $T_{1}$ MRI contrast agents and combination of low molecular weight $T_{1}$ MRI contrast agents with different types of carriers have been investigated. Different types of materials for forming secure coating layers of SPIO and novel superparamagnetic particles with higher relaxivity values have been explored. Various types of ligands were applied to improve the capability to target tumor for both $T_{1}$ and $T_{2}$ contrast agents. Furthermore, MRI contrast agents for detection of tumor metabolism were also pursued.
\end{abstract}

Keywords: magnetic resonance imaging (MRI), magnetic resonance imaging (MRI) contrast agent, tumor, metabolism, diagnosis

\section{INTRODUCTION}

In comparison with other diagnosis techniques such as X-ray computed tomography (CT), positron-emission tomography (PET), single photon-emission computed tomography (SPECT) and ultrasound, magnetic resonance imaging (MRI) is noninvasive and can provide tomographic information of whole animals with a high spatial resolution and soft tissue contrast [1,2]. There are many types of MRI techniques,

*Corresponding Author: Ye Liu, Institute of Materials Research and Engineering, A*STAR (Agency for Science, Technology and Research), 3 Research Link, Singapore 117602. Phone: (65) 68748105. Fax:(65) 6872 7528. E-mail: ye-liu@imre.a-star.edu.sg. Other authors: Weiren Cheng: a0033015@nus.edu.sg; Yuan Ping: pingy@imre.a-star.edu.sg; Yong Zhang: biezy@nus.edu.sg; Kai-Hsiang Chuang: Chuang_kai_hsiang@sbic.a-star.edu.sg. 
including the longitudinal relaxation time $\left(T_{1}\right)$-weighted imaging with a hyper-intense signal and the transverse relaxation time $\left(T_{2}\right)$-weighted imaging with a hypo-intense signal. The key challenge in MRI technique is its low diagnosis sensitivity. Currently, $40-50 \%$ of MRI scans use contrast agents that contain magnetic metal ions to enhance the intensity of signal $[1,3]$. The contrast agents for $T_{1}$-weighted MRI (i.e., $T_{1}$ contrast agent) usually contain lanthanide or transitional metal ion $\left(\mathrm{Gd}^{3+}\right.$ or $\left.\mathrm{Mn}^{2+}\right)$ that is chelated to reduce serious side effects [4-6]. The contrast agents for $T_{2}$-weighted MRI (i.e, $T_{2}$ contrast agent) normally consists of superparamagnetic nanoparticles with coating layers [6].

Since nuclear magnetic resonance was explored for diagnosis of disease in 1971 [7], MRI has been well developed for diagnosis of various diseases. For tumor diagnosis, MRI contrast agents are useful to obtain good contrast for differentiating tumor from healthy tissues, and indicating tumor malignant status and the treatment efficacy. There are many seminal reviews on MRI contrast agents, most of which are generally about MRI contrast agents for diagnosis of various diseases [4-6]. In this review, we focus on contrast agents for tumor diagnosis based on $T_{1^{-}}$and $T_{2}$-weighted MRI. The contrast agents used in clinical tumor diagnosis are described first, followed by an update of the progress in developing $T_{1}$ MRI contrast agents through exploring new chelates and combining low molecular weight $T_{1}$ MRI contrast agents with various types of carriers. The progress in developing $T_{2}$ MRI contrast agents through forming secure coating layers for SPIO and preparing new superparamagnetic cores is discussed. The approaches to improving targeting capability of both $T_{1}$ and $T_{2}$ MRI contrast agents via either passive targeting or active targeting are covered. Also discussed is the research on developing MRI contrast agents for detection of tumor metabolism.

\section{2. $T_{1}$ MRI CONTRAST AGENTS}

\section{1. $T_{1}$ MRI Contrast Agents for Clinical Tumor Diagnosis}

As shown in Figure 1, several types of $T_{1}$ MRI contrast agents, i.e., Gd-DTPA (Magnevist $^{\circledR}$ ), Gd-EOB-DTPA (Eovist ${ }^{\circledR}$ ) and Gd-DTPA-BMA (Omniscan ${ }^{\circledR}$ ), have been employed for clinical tumor diagnosis. Pettersson et al. showed that Gd-DTPA enhanced only the richly vascularized parts and the surrounding of the soft tissue tumors in 10-15 minutes after injection [8]. For the detection of mediastinal lymph nodes, Gd-DTPA-enhanced MRI could provide a diagnosis with a sensitivity of $100 \%$, an accuracy of $97 \%$ and a specificity of $91 \%$ as compared to $62 \%, 74 \%$ and $100 \%$ for non-enhanced MRI, respectively [9]. However, Gd-DTPA might not be helpful in screening other types of cancer. Hawnaur et al. demonstrated that it is complicated to identify tumor in bladder using Gd-DTPA-enhanced MRI due to the excretion of GdDTPA in urine and changes in bladder volume, which could affect the interpretation of results; it was also not reliable in determining the effectiveness of the radiotherapy due to structural changes in the bladder after radiotherapy [10].

Gd-EOB-DTPA is suitable for liver tumor diagnosis due to its good liver-specificity [11]. Vander et al. reported that Gd-EOB-DTPA was taken preferably by an excised and perfused rat liver than Gd-DTPA [12]. Shimada et al. showed that Gd-EOB-DTPAenhanced MRI was more accurate and sensitive in detecting small hepatic metastases 


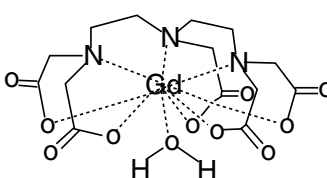

Gd-DTPA (Magnevist ${ }^{\circledR}$ )

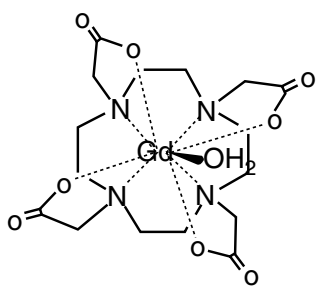

Gd-DOTA (Dotarem ${ }^{\circledR}$ )

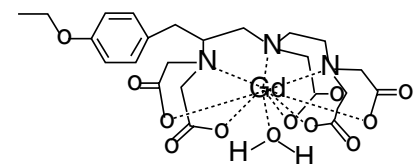

Gd-EOB-DTPA (Eovist ${ }^{\circledR}$ )

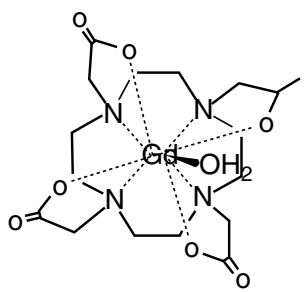

Gd-HP-DO3A (ProHance $\left.{ }^{\circledR}\right)$

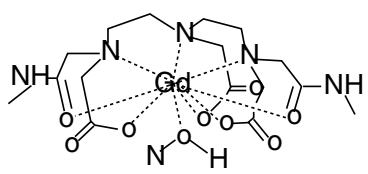

Gd-DTPA-BMA (Omniscan $\left.{ }^{\circledR}\right)$

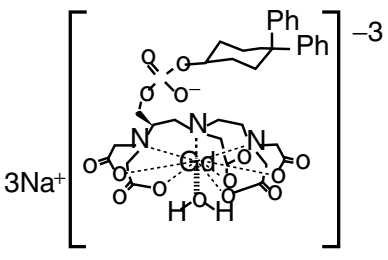

MS-325

Figure 1. Typical low molecular weight $T_{1}$ MRI contrast agents used in clinical tumor diagnosis.

of a diameter smaller than $2 \mathrm{~cm}$ than diffusion-weighted MRI [13]. Gd-EOB-DTPA induced a much better tumor enhancement of solid hepatocellular carcinoma lesion of rats than Gd-DTPA and Mn-DPDP. The Gd-EOB-DTPA almost disappeared in 24 hours while a high concentration of Mn-DPDP still remained in the liver [14].

Recently, US FDA approved clinical use of MS-325 in magnetic resonance angiography (MRA). MS-325 can form complex with endogenous serum albumin via hydrophobic interaction without covalent linkages [15-18], and provide $r_{1}$ of a value 10 times higher and a longer vascular residence time than non-protein-binding contrast agents. The reversible bonding between albumin and MS-325 could facilitate the excretion of MS-325 and avoided poor clearance. MS-325 was also used in the assessment of capillary permeability in rat breast tumor [19].

Although several types of $T_{1}$ MRI contrast agents have been employed for clinical tumor diagnosis, their sensitivities still need to be improved in terms of higher $r_{1}$ value and/or capability to target tumor.

\subsection{New $T_{1}$ MRI Contrast Agents for Tumor Diagnosis Under Investigation}

Two approaches are discussed below regarding development of $T_{1}$ MRI contrast agents for tumor diagnosis with improved sensitivity, i.e., low molecular weight $\mathrm{Gd}^{3+}$ complex composed of suitable chelates and targeting ligands, and low molecular weight $T_{1}$ MRI contrast agents combined with various carriers.

\subsubsection{Low Molecular Weight T1 MRI Contrast Agents}

One of the most promising chelates for preparing $T_{1}$ MRI contrast agents for tumor diagnosis is porphyrin-based compounds with possible multi-functionality. Porphyrin could function as a ligand and was potentially applicable for cancer photodynamic 
therapy [20]. As the ring of porphyrin is too small to accommodate $\mathrm{Gd}^{3+}$ ions securely in vivo [21], porphyrin-like synthetic macrocyle, texaphyrin, was explored as a chelate of $\mathrm{Gd}^{3+}$ instead, which could provide a longer MRI contrast enhancement of the V2 carcinoma than Gd-DTPA [22]. Another type of contrast agent obtained from texaphyrin, Motexafin Gd, could provide MRI contrast enhancement of brain tumor and killed the cancer cells via redox cycling simultaneously $[23,24]$.

Enhanced targeting of MRI contrast agents to tumor sites can improve the sensitivity significantly. Various types of ligands have been explored to improve the tumor specificity of low molecular weight $T_{1}$ MRI contrast agents. Arginine-glycine-aspartic acid (RGD) peptide is well known for its high and specific affinity for $\alpha_{v} \beta_{3}$-integrins which are over-expressed in endothelial cells during angiogenesis of tumors. Park et al. reported a liver specific contrast agent, cyclic RGD conjugated Gd-DOTA (Gd-DOTARGD) [25]. Gd-DOTA-RGD could produce a high signal intensity of the tumor, but almost lost this enhancement when the $\alpha_{v} \beta_{3}$-integrins were blocked [25]. Deoxyglucosamine conjugated Gd-DTPA (Gd-DTPA-DG) was developed to target the hypermetabolic cancer cells because deoxyglucosamine was rapidly taken up by tumor due to the over-expressed glucose transporters [26]. Gd-DTPA-DG could provide a higher MRI enhancement of A549 tumor than Gd-DTPA and a higher retention rate because the metabolism pathway was blocked by the deoxyglucosamine analog [26]. MRI contrast agents were also developed to target the overexpression of estrogen and estrogen related progesterone receptors in breast and ovarian cancers. Sukerkar et al. conjugated progesterone to Gd-DO3A to improve the cellular uptake by around 3 times higher in two breast cancer cell lines and provided a higher contrast enhancement of the xenograft tumors in nude mice [27]. Pais et al. developed another type of breast cancer specific MRI contrast agent, EPTA-Gd, by conjugating 17b-estradiol to pyridinetetraacetate-Gd (PTA-Gd) for differentiating estrogen receptors-transfected $\mathrm{PR}(+)$ from wild-type PR(-) human breast cancer cells [28].

\subsubsection{Low Molecular Weight $T_{1}$ MRI Contrast Agents Combined with Carriers}

Combination of low molecular weight $T_{1}$ MRI contrast agents with carriers including polymers and nanomaterials can produce contrast agents with a high payload of chelated $\mathrm{Gd}^{3+}$, normally a higher $r_{1}$ value, and enhanced tumor targeting capability. One factor contributing to the enhanced targeting capability is the enhanced permeability and retention (EPR) effect owing to accumulation of complexes of carriers and low molecular weight $T_{1}$ contrast agents, which are larger, in tumors with loosely vascular structures [29]. However, the possible release of free $\mathrm{Gd}^{3+}$ was observed from some liposome loaded with low molecular weight $T_{1}$ MRI contrast agent, which showed a long retention time [30]. Therefore, the safety issues of the complex of carriers and low molecular weight $T_{1}$ contrast agent should be taken into account as well.

\subsubsection{Water-Soluble Polymer as Carriers}

Many types of water soluble polymers, including linear polymers, dendrimers, and proteins, have been explored for carrying low molecular weight $T_{1}$ MRI contrast agents. Generally, such conjugation limits the rotation and motion of the chelated $\mathrm{Gd}^{3+}$ leading to a higher $r_{1}$ value [31-34]. 
Gd-DTPA conjugated polylysine was able to accumulate in grafted tumor in rat models and therefore provided an enhanced imaging for several days [35]. Gd-DTPA conjugated polyaspartamide demonstrated a preferential uptake and therefore an enhanced MRI contrast in hepatoma in mouse models [36]. A high molecular weight polyglutamic acid based MRI contrast agent exhibited an improved tumor accumulation [37]. Low molecular weight $T_{1}$ MRI contrast agents were also conjugated with polysaccharides including dextran, starch, inulin and oligoglucoamines. Conjugates of Gd-DTPA with dextran or oligopolyglucoamines were investigated for delineation of tumor in rabbits [38], while Gd-DO3A conjugated carboxymethyl hydroxyethyl starch showed the ability to image leaky vasculature of tumor [39]. Galatose units targeting the lectin asialoglycoprotein receptor (ASGPR) expressed on liver hepatocytes [40] were explored for imaging of hepatocyte carcinoma through combination with either DOTA [41] or DTPA [40, 42].

In comparison with linear polymers, dendrimers have well-defined, rigid dendritic structures together with abundant terminal groups. The conjugation to the terminal groups produces dense peripheral layers of low molecular weight $T_{1}$ MRI contrast agents which can induce high $r_{1}$ values. For example, the $r_{1}$ of G6-(C-DOTA-Gd) 115 shown in Figure 2, prepared using a preligation technique, could reach $89.1 \mathrm{mM}^{-1} \mathrm{~s}^{-1}$ as compared to $4.2 \mathrm{mM}^{-1} \mathrm{~s}^{-1}$ for DOTA-Gd [31]. It was also found that G6 or G7 dendrimers provided the highest $r_{1}$ values, while protonation of amines [43,44] and formation of adducts $[45,46]$ could further improve the values by forming more rigid and open structures with a lower internal motion. Therefore, a higher level of contrast enhancement of tumors could be obtained using a lower amount of PAMAM [47-50] and polylysine dendrimer [51] conjugated with low molecular weight $T_{1}$ MRI contrast agents. PEGylated and non-PEGylated Gd labeled dendrimers had a $r_{1}$ value higher than $20 \mathrm{mM}^{-1} \mathrm{~s}^{-1}$ together with a longer retention time [52-54]. Targeting ligands, e.g., OST7 [55], murine monoclonal IgG1, folic acid which targets folate receptor (hFR) [56-59], and cyclic RGD as an angiogenesis marker [60], were applied to improve active targeting of the conjugates of PAMAM and low molecular weight $T_{1}$ MRI contrast agents. Also, dendrimer nanoclusters (DNCs) with folic acid as ligand were developed with a high payload of low molecular weight $T_{1}$ MRI contrast agents [61]. In order to improve biocompatibility, biodegradable esteramide dendrimer was combined

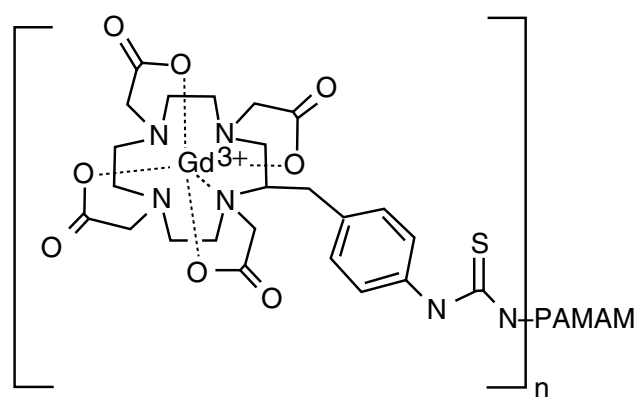

Figure 2. Gd-DOTA conjugated PAMAM [31]. Used with permission. 
with low molecular weight $T_{1}$ MRI contrast agents [32] which showed a low toxicity similar to Gd-DTPA [62, 63].

Low molecular weight $T_{1}$ MRI contrast agents were also combined with proteins such as albumin [64, 65], IgG and fibrinogen [66] and could increase $r_{1}$ by 3 folds. Albumin-Gd-DTPA was employed to monitor the histological profile of tumor and abnormal capillary permeability in cancer models [67-71]. The changes in capillary permeability could estimate angiogenic activity and the effects of pharmacological stress [72], radiation [73] and toxins [74]. The combination with certain types of proteins could improve the tumor targeting capability. Through the interaction between biotin and avidin, $\mathrm{Gd}^{3+}$-labeled avidin was used to image the dynamic response of tumors to etoposide treatment in mice [75] and breast cancer [76]. Antibody was also explored to deliver MRI contrast agents to tumor specifically. It was shown that antibody labeled Gd-DTPA could visualize melanoma [77, 78], human rectal carcinoma [79] and human gastrointestinal cancer [80, 81]. However, many results have shown that conjugation could destroy the immunereactivity of antibodies; therefore, the targeting capability of these MRI contrast agents was limited [82, 83].

\subsubsection{Nanomaterials as Carriers}

With the advancement in nanotechnology, many types of nanomaterials have been developed, such as polymer micelles and vesicles, liposomes and lipid particles, viral particles, carbon nanotubes and fullerenes, gold nanoparticles, and silica particles; most of them have been explored as carriers of $\mathrm{Gd}^{3+}$ as MRI contrast agents for tumor diagnosis.

Ratzinger et al. reported Gd-DTPA and Gd-DOTA labeled poly(lactic-co-glycolic acid) (PLGA) nanoparticles with an $r_{1}$ of $17.5 \mathrm{mM}^{-1} \mathrm{~s}^{-1}$ [84]. In another work, GdDOTA was conjugated to poly(ethylene glycol) (PEG)-polylysine which could form micelles [85]. Micelles containing low molecular weight $T_{1}$ contrast agents could also be obtained by mixing Gd-DTPA conjugated PEG-b-poly(aspartic acid) with polyallylamine/protamine or Gd-DOTA conjugated PEG-polylysine with poly(methacrylic acid) [86, 87] via forming polyelectrolyte complex. The $r_{1}$ of the polyelectrolytes micelles containing Gd-DTPA was reduced to 2.1 and $3.6 \mathrm{mM}^{-1} \mathrm{~s}^{-1}$ but was increased to 10 and $11 \mathrm{mM}^{-1} \mathrm{~s}^{-1}$, respectively, once the micelles were dissociated $[86,87]$. All these micelles containing low molecular weight $T_{1}$ contrast agents showed a preferential accumulation in tumors [46, 85]. Gd-DTPA loaded into PEG-bpoly(glutamic acid)/bis(nitrato) (trans-1-1, 2-diaminocyclohexane) platinum(II) micelle complex resulted in an increase in $r_{1}$ value by 24 times [88]. Theranostic systems such as Gd-DOTA conjugated to unimolecular micelles which composed of fourth generation hyperbranched polyester (Boltorn H40) cores, hydrophobic $\varepsilon$-caprolactone (PCL) inner layers and hydrophilic poly(oligo(ethylene glycol) shells coated with folic acid (FA). Paclitaxel, an anti-cancer drug, was encapsulated in the hydrophobic PCL layers with a drug loading capacity of $6.67 \%$. That system showed an $r_{1}$ value of 18.14 $\mathrm{mM}^{-1} \mathrm{~s}^{-1}$ and a long retention time of up to 20 hours [89]. Other theranostic systems with higher $r_{1}$ values have also been reported with FA as targeting moiety and doxorubicin as drug [90-92]. 
Bui et al. incorporated Gd-DTPA into PEG-coated phospholipid nanoparticles (LNP), which showed a very high $r_{1}$ value of $134.8 \mathrm{mM}^{-1} \mathrm{~s}^{-1}$; the Gd-DTPA loaded LNP was excreted from the body through the biliary system instead of the renal system due to its lipid nature [93]. Low molecular weight $T_{1}$ MRI contrast agents were loaded into liposomes in several ways as shown in Figure $3[6,94]$. For example, ensomes with reduced $r_{1}$ values and memsomes with higher $r_{1}$ values were formed when low molecular weight $T_{1}$ MRI contrast agents were trapped in the inner parts and the membranes of liposomes, respectively. These systems demonstrated an enhanced passive targeting of tumor such as liver tumor [95]. For active targeting, RGD was employed to label PEGylated liposomes encapsulated with Gd-DTPA and provided a higher MRI contrast enhancement of human lung cancer in xenograft mice [96]. Transferrin, which is over-expressed in many cancerous cells, was used to label liposomes loaded with Gd-DTPA to image the detailed pathway of the liposomes in the human prostate cancer cells inoculated in nude mice [97]. These liposomes entered the peripheral region of the tumor reflected by higher signal intensity observed in 10 minutes after injection of the contrast agent, and then entered the cells via endocytosis where Gd-DTPA was released. Finally liposomes and the released Gd-DTPA were

(a)

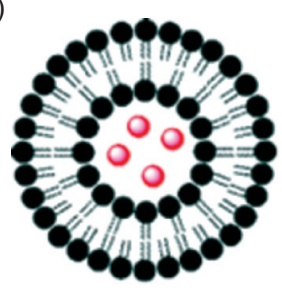

(b)

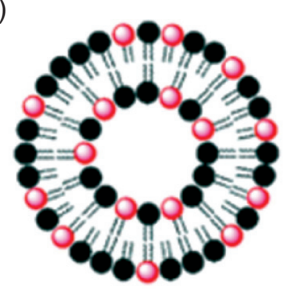

(c)

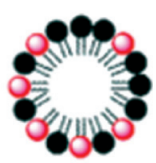

(d)

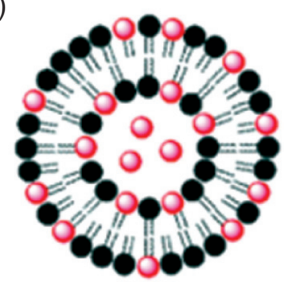

(e)

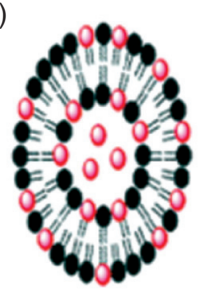
Paramagnetic species
Polar head
m Hydrophobic tall

Figure 3. Schematic representations of (A) ensome, (B) memsome, (C) micelle, (D) combined ensome-memsome, and (E) shrunken lipoCEST agent [6]. Used with permission. 
pumped out by the cancer cells and were then accumulated in the necrotic area due to the lack of washout mechanism indicated by the significant increase in signal intensity in 60 minutes after injection [97]. Moreover MRI based on chemical exchange saturation transfer (CEST) has a high potential to provide better imaging [6, 94, 98]. MRI contrast agents for this technology can be obtained by loading low molecular weight $T_{1}$ MRI contrast agents into non-spherical liposomes to form LipoCEST agents as shown in Figure 3E.

Nanosized silica has been explored for loading low molecular weight $T_{1}$ MRI contrast agents. Gd-DTPA was conjugated to PEG functionalized mesoporous silica nanospheres (MSN) with anisamide as a targeting ligand via cleavable disulfide linkage, and provided an $r_{1}$ value up to $25.7 \mathrm{mM}^{-1} \mathrm{~s}^{-1}$ [99]. Such nanospheres could be taken up by AsPC-1 pancreatic cancer cells, and the in vivo results indicated that Gd-DTPA was cut from MSN in 15 minutes after injection, reflected by a strong imaging enhancement of the bladder, due to rapid reduction of the disulfide linkage by plasma thiols [99]. The biocompatibility of silica nanoparticles was investigated using $\mathrm{Gd}_{2} \mathrm{O}_{3}$ doped mesoporous silica nanocomposite, which indicated that silica particles showed a low toxicity in cell lines and no potential immunotoxicity [100]. Silica nanoparticles coated with $\mathrm{Gd}_{2}\left(\mathrm{CO}_{3}\right)_{3}$ were also prepared and exhibited a low $r_{1}$ value of $1.6 \mathrm{mM}^{-1} \mathrm{~s}^{-1}$ [101].

Low molecular weight $T_{1}$ MRI contrast agents were also conjugated with other types of nanomateirals. Conjugation with viral capsids could significantly improve $r_{1}$ values [102]. Anchoring low molecular weight $T_{1}$ MRI contrast agent onto Au nanoparticles could improve $r_{1}$ value by several times $[103,104]$ and benefit multimodal cell imaging [104]. When Gd was loaded into fullerenes, gadofullerene formed with either PEG shells or succinic acid shells provided $r_{1} 50$ to 60 times higher than Gd-DTPA, and the gadofullerene was tested for imaging of brain tumor in rat models [105, 106].

\section{3. $T_{2}$ MRI CONTRAST AGENTS}

The majority of $T_{2}$ MRI contrast agents contain superparamagnetic iron oxide (SPIO) nanoparticles which are composed of either maghemite $\left(\gamma-\mathrm{Fe}_{2} \mathrm{O}_{3}\right)$ or magnetite $\left(\mathrm{Fe}_{3} \mathrm{O}_{4}\right)$ phases prepared by various methods including co-precipitation and hydrothermal procedures. SPIO can provide a high proton relaxivity with a typical $r_{2}$ value of $100 \mathrm{mM}^{-1} \mathrm{~s}^{-1}$ and $r_{1}$ value of $30 \mathrm{mM}^{-1} \mathrm{~s}^{-1}$, together with a prolonged contrast enhancement [107-109]. Pure SPIO possesses good biocompatibility due to low cytotoxicity and biodegradability with degraded SPIO entering the iron reservoirs such as hemoglobin in red blood cells $[110,111]$. However, a suitable coating layer is necessary to avoid formation of aggregates and provide a long circulation in the blood stream by avoiding uptake by the reticuloendothelial system (RES) and excretion through the renal filtration [112-114].

\section{1. $T_{2}$ MRI Contrast Agents for Clinical Tumor Diagnosis}

Dextran-coated SPIO, e.g., Ferumoxide ${ }^{\circledR}$ and Ferrixan/Ferucarbotran ${ }^{\circledR}$, have been tested for clinical tumor dignosis [6]. Ferumoxide ${ }^{\circledR}$ nanoparticles with diameters of $80-150 \mathrm{~nm}$ are used for MR imaging of liver and spleen, Ferrixan/Ferucarbotran with a diameter of $62 \mathrm{~nm}$ are used for liver, and both contain SPIO of a diameter of $4.2 \mathrm{~nm}$. These contrast 
agents are prepared via copreciptation method in the presence of dextran. The dextran coating layers are formed via multiple cooperative low-energy interactions between dextran and SPIO including van der Waals force, electrostatic and hydrophobic interactions [115]. Pharmacokinetic and toxicity studies have revealed that the dextranbased nanomaterials are non-toxic and biodegradable with extended vascular retention times [116].

$T_{2}$ MRI contrast agents have been demonstrated to be useful for imaging liver tumors by providing a strong contrast between healthy and cancerous tissues. This is due to a preferential uptake of contrast agents by reticuloendothelial cells such as Kuppfer cells which are absent or in low concentration in tumors [117, 118]. Clinical studies have shown that Ferumoxide ${ }^{\circledR}$ could detect hepatic tumors with a high accuracy as the nanoparticles accumulate exclusively in healthy liver tissues [119]. Ferumoxide ${ }^{\circledR}$ tended to exhibit a two-phase blood clearance with a half-life of the first phase and the second phase ranging from 4.4-22.2 minutes and 79-309 minutes, respectively, after intravenous injection in patients with liver metastases [120]. Reimer et al. have shown that SPIO enhanced $T_{2}$-weighted MRI was more accurate in the detection of focal hepatic lesions than non-enhanced $T_{1^{-}}$and $T_{2}$-weighted MRI and contrast-enhanced spiral computed tomography (CT) [121]. Ferumoxide ${ }^{\circledR}$ has also been used for detecting focal splenic tumors through observing a significant increase in signal intensity of spleen but not the tumor [122]. This allow a more accurate identification of lesions than other diagnostic methods such as sonography, contrast-enhanced CT, and unenhanced MRI. The clinical investigation was also extended to lymph nodes, and smaller SPIObased contrast agents were found to accumulate in lymph nodes [123, 124]. Specifically, smaller SPIO-based contrast agents with a diameter of ca. $30 \mathrm{~nm}$ were extravasated from the vasculature to the interstitial space and were then transported to the lymph nodes via the lymphatic vessels. Lymph nodes containing cancerous tissues lack the necessary macrophages to phagocytize SPIO; as a result, the accumulation of SPIO in healthy tissues shortened $T_{2}$ signal, and significantly increased the positive predictive values and accuracy of node metastases diagnosis [125].

The drawback of these $T_{2}$ MRI contrast agents used in clinical tumor diganosis lies in that the non-crosslinked dextran coating layer can be removed by the surrounding medium. However, there are safety concerns about the cross-linking agents used in forming the cross-linked dextran layer coated on SPIO (CLIO) via reaction with epichlorohydrin [126], although CLIO has been applied in clinical studies of prostate cancers $[117,127]$ and other cancers $[128-130]$.

\subsection{New $T_{2}$ MRI Contrast Agents Under Investigation}

In order to develop better $T_{2}$ MRI contrast agents for tumor diagnosis, superparamagnetic nanoparticles with a higher relaxivity, secure coating layers of SPIO and an improved tumor targeting capability have been pursued.

\subsection{1. $T_{2}$ MRI Contrast Agents with New Superparamagnetic Nanoparticles}

The magnetic properties of superparamagnetic particles are affected by size, shape, and defect concentration. There are many different methods to synthesize 
superparamagnetic particles [131]. The most common fabrication method is the Massart's procedure whereby base is added to an aqueous solution of ferrous $\left(\mathrm{Fe}^{2+}\right)$ and ferric $\left(\mathrm{Fe}^{3+}\right)$ ions with a 1:2 stoichiometric ratio under an oxygen free environment [132]. However, SPIO produced in this process has a varied size and a low saturation magnetization value of 30-50 emu/g due to impurities and crystal defects [133]. In contrast, thermal decomposition of organometallic reagents could yield SPIO with a well-defined size and a high saturation magnetization value $>70 \mathrm{emu} / \mathrm{g}$ [134]. In order to further improve the magnetic performance, metal-doped SPIO nanoparticles as depicted in Figure 4 were developed, and the $\mathrm{MnFe}_{2} \mathrm{O}_{4}$ produced had a low cytotoxicity and exhibited a very high $r_{2}$ value of $350 \mathrm{mM}^{-1} \mathrm{~s}^{-1}$ [135]. However, most of these particles were prepared in organic solvents, and transformation into aqueous solution was necessary for further coating. In addition, SPIO nanoparticles prepared by precipitation in alkaline solution are more suitable for in vivo purposes, and the SPIO nanoparticles prepared by other procedures are limited to in vitro applications [136].

\subsection{2. $T_{2}$ MRI Contrast Agents with Secure Coating Layers}

Beyond dextran, other types of polymers [137] including PEG [138-140] and PEG containing copolymers [141-143] were explored as coating layers for SPIO. PEG coating layers on SPIO particles could be achieved via forming cross-linked layers from siliane [144], anchoring dopamine species [145], and encapsulating SPIO nanoparticles in micelles [146]. Silica-coated SPIO nanoparticles were also developed as $T_{2}$ MRI contrast agents [147]. Silica layer, which could be further functionalized with PEG, could be formed directly on SPIO nanoparticles [148] or through a gut layer [149]. Recently, mesoporous silica nanoparticles were loaded with SPIO as MRI contrast agent [150].

\subsection{3. $T_{2}$ MRI Contrast Agents with Ligands}

SPIO based contrast agents without targeting capability is only useful for the diagnosis of tumors in RES organs where large quantities of resident macrophages exist. For the detection of cancerous tissues in other parts of the body, it is necessary to integrate ligands for active targeting. Many type of ligands, such as small molecules, proteins, and oligonucleotides, have been conjugated to dextran layers coated on SPIO through conventional chemical methods, click chemistry methods and cycloaddition methods as depicted in Figure 5 [151-153]. Among 146 different types of small molecules with varied solubility in aqueous solution and chemical diversity, glycine-conjugated CLIO was identified to be capable of targeting active macrophages associated with tumors with proangiogenic and immunosuppressive properties [154], but not resting macrophages [155]. On the other hand, CLIO conjugated with 3,3',4,4'benzophenontetracarboxylic dianhydride was able to target resting macrophages [156].

Anti-vascular cell adhesion molecules-1 (VCAM-1) antibodies [157], VHS peptide [158] and VHPKQHR peptide $[159,160]$ were explored to target $T_{2}$ MRI contrast agents to cells with VCAM expression which is related to tumor angiogenesis. SPION coated with dextran conjugated with folate showed a rapid and efficient uptake via receptor-mediated endocytosis by both human nasopharyngeal epidermal carcinoma cells (KB cells) overexpressing folate receptors and subcutaneous tumor (xenografts grown from implanted KB cells) in mouse models [161, 162]. Transferrin-conjugated 
(a)
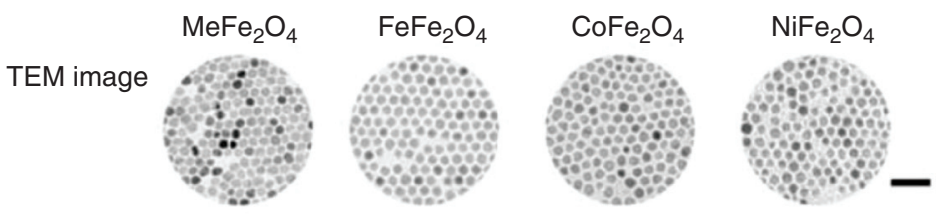

(b)

Mass magnetization 110 (emu/g)

101

99

85

(c) Magnetic spin structure
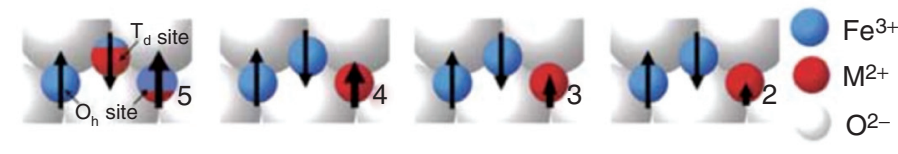

(d) Magnetic moment $5 \mu_{\mathrm{B}}$ $4 \mu_{\mathrm{B}}$ $3 \mu_{\mathrm{B}}$ $2 \mu_{\mathrm{B}}$

(e)

T2-weighted
MRI
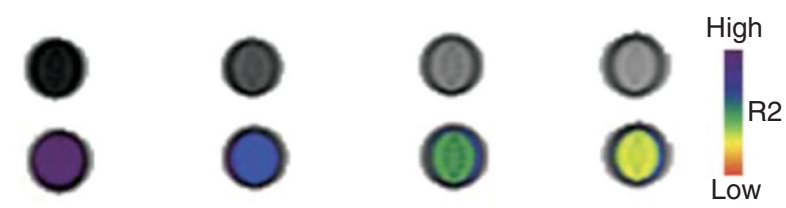

(f)

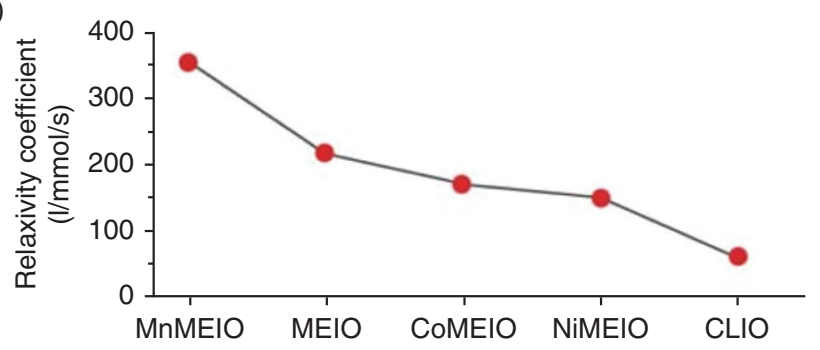

Figure 4. Metal-doped superparamagnetic iron oxide nanoparticles. (a) TEM images of $\mathrm{MnFe}_{2} \mathrm{O}_{4}$ (MnMEIO), $\mathrm{Fe}_{3} \mathrm{O}_{4}$ (MEIO), $\mathrm{CoFe}_{2} \mathrm{O}_{4}$ (CoMEIO) and $\mathrm{NiFe}_{2} \mathrm{O}_{4}$ (NiMEIO). All nanoparticles were of $\sim 12 \mathrm{~nm}$ with narrow size distributions $(\sigma<\sim 8 \%)$. Scale bar: $50 \mathrm{~nm}$. (b) Mass magnetization values of $\mathrm{MFe}_{2} \mathrm{O}_{4}$. (c, d) Schematics of spin alignments of magnetic ions in spinel structures under external magnetic field, and magnetic spin moment of $\mathrm{MFe}_{2} \mathrm{O}_{4}$ nanoparticles. In face-centered cubic lattices of oxygen, the magnetic spins at $\mathrm{O}_{\mathrm{h}}$ sites aligned in parallel with the direction of the external magnetic field, whereas those at $T_{d}$ sites aligned antiparallel. $\mathrm{MnFe}_{2} \mathrm{O}_{4}$ has the highest mass magnetization value, with a magnetic spin magnitude of $5 \mu_{\mathrm{B}}$. (e, f) T2-weighted spin echo MR images, their color maps and relaxivity (R2) of a series of MEIO nanoparticles at $1.5 \mathrm{~T}$. In (f), the R2 of CLIO is also presented for comparison. Consistent with the mass magnetization results, MnMEIO displays the strongest MR contrast effect (darkest MR image, violet in color map) with the highest R2 coefficient. Mass magnetization value, MR contrast, and $\mathrm{R} 2$ coefficient decrease as $\mathrm{M}^{2+}$ changed from $\mathrm{Mn}^{2+}$ to $\mathrm{Fe}^{2+}, \mathrm{Co}^{2+}$ and $\mathrm{Ni}^{2+}[135]$. Used with permission. 


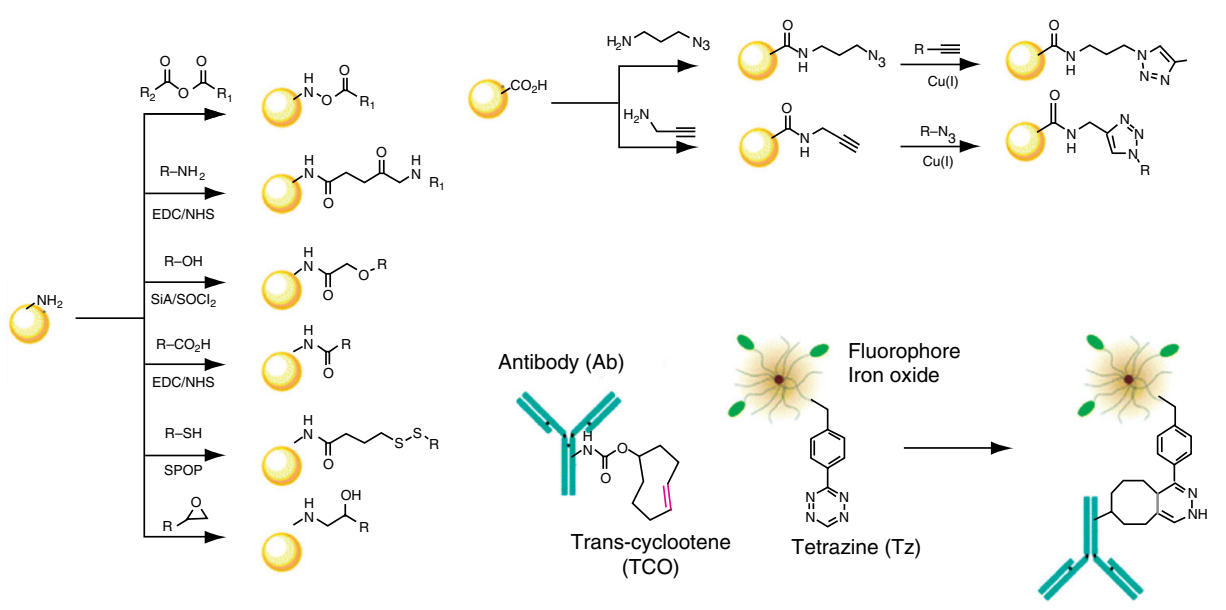

Figure 5. Conjugation chemistry to attach small molecules to CLIO [152]. Used with permission.

dextran-coated SPIO was tested to target tumors with a higher level of transferrin receptor expression [163]. Furthermore, RGD was also explored to enhance the targeting of SPIO to tumors [164]. It was shown that RGD-modified SPIO nanoparticles could significantly enhance the sensitivity of MRI for early stage tumor detection [165].

\section{MRI CONTRAST AGENTS RESPONSIVE TO TUMOR METABOLISM}

It is very important to develop diagnosis techniques to reflect tumor metabolism, e.g., apoptosis, glycolysis, $\mathrm{pH}$, redox, and hypoxia, which are related to the malignant status and therapeutic responses of cancers. It is well-known that particular metabolites are produced from tumor with a certain metabolism; therefore, magnetic resonance spectroscopy (MRS), which can identify the particular metabolites, is powerful for monitoring tumor metabolism $[1,166]$. When MRI is applied to detect tumor metabolism, it is a prerequisite to identify the relationships between signal intensity and particular tumor metabolites or biomarkers. However, so far there are very few reports in this area.

By exploring interaction with the phosphatidylserine on the surface of apoptotic cells, C2A domain of synaptotagmin I loaded with SPIO [167] and Gd-DTPA [168] were applied for image apoptosis of tumor cells. GdTODA-4AmP5 ${ }^{-}$, whose proton exchange rate changes with $\mathrm{pH}$, was developed and explored to detect $\mathrm{pH}$ of tumor [169]. Iwaki et al. also developed a pH-responsive Gd-based contrast agent, $4 \mathrm{NO}_{2} 2 \mathrm{MeOSAGd}$. The relaxivity of $4 \mathrm{NO}_{2} 2 \mathrm{MeOSAGd}$ was increased by 1.8 times after it was reduced to $4 \mathrm{NH}_{2} 2 \mathrm{MeOSAGd}$ via an enzymatic reaction [170].

\section{CONCLUSION}

Both $T_{1}$ and $T_{2}$ MRI contrast agents have been employed to improve the accuracy, sensitivity and specificity of tumor diagnosis with MRI. Many efforts are still needed 
to overcome the hurdles related to the low sensitivity and specificity of current MRI contrast agents.

Novel chelating approaches can produce $T_{1}$ MRI contrast agents with much high $r_{1}$ values, such as forming complexes of $\mathrm{Gd}^{3+}$ with fullerenes and some proteins, but extensive examinations of their stability, retention behaviors and safety are still needed. The combination of low molecular weight $T_{1}$ MRI contrast agents with carriers can yield a higher sensitivity and specificity for MRI. However, suitable carriers, including hyperbranched polymers, dendrimers and nanomaterials, with good biocompatibility and safety are still desired.

$T_{2}$ MRI contrast agents for clinical applications use biocompatible SPIO prepared by coprecipitation method, but it is still a challenge to produce biocompatible superparamagnetic nanoparticles with a well-defined size, a high saturation magnetization value, and good batch reproducibility. Meanwhile, it is still crucial to develop secure coating layer for superparamagnetic nanoparticles together with improved targeting capability.

For detection of tumor metabolism using MRI technique, more efforts in developing MRI contrast agents responsive to particular metabolites or biomarkers are needed.

\section{ACKNOWLEDGEMENTS}

We appreciate the finance support from A*Star under JCO program and SingaporeChina Joint Research Programme.

\section{CONFLICT OF INTEREST}

The authors declare no competing financial interests.

\section{REFERENCES}

[1] Brindle K. New approaches for imaging tumour responses to treatment. Nature Reviews Cancer, 2008, 8:94-107.

[2] Weissleder R, Pittet MJ. Imaging in the era of molecular oncology. Nature, 2008, 452:580-589.

[3] Aime S, Castelli DD, Crich SG, Gianolio E, Terreno E. Pushing the Sensitivity Envelope of Lanthanide-Based Magnetic Resonance Imaging (MRI) Contrast Agents for Molecular Imaging Applications. Accounts of Chemical Research, 2009, 42:822-831.

[4] Caravan P, Ellison JJ, McMurry TJ, Lauffer RB. Gadolinium(III) chelates as MRI contrast agents: Structure, dynamics, and applications. Chemical Reviews, 1999, 99:2293-2352.

[5] Lin WB, Hyeon T, Lanza GM, Zhang MQ, Meade TJ. Magnetic Nanoparticles for Early Detection of Cancer by Magnetic Resonance Imaging. Mrs Bulletin, 2009, 34:441-448.

[6] Villaraza AJL, Bumb A, Brechbiel MW. Macromolecules, Dendrimers, and Nanomaterials in Magnetic Resonance Imaging: The Interplay between Size, Function, and Pharmacokinetics. Chemical Reviews, 2010, 110:2921-2959.

[7] Damadian RV. Tumor Detection by Nuclear Magnetic Resonance. Science, 1971, 171:1151-1153.

[8] Pettersson H, Eliasson J, Egund N, Rooser B, Willen H, Rydholm A, Berg NO, Holtas S. GadoliniumDTPA enhancement of soft tissue tumors in magnetic resonance imaging - Preliminary clinical experience in five patients. Skeletal Radiology, 1988, 17:319-323.

[9] Crisci R, Di Cesare E, Lupattelli L, Coloni GF. MR study of N2 disease in lung cancer: Contrastenhanced method using gadolinium-DTPA. European Journal of Cardio-thoracic Surgery, 1997, 11:214-217. 
[10] Hawnaur JM, Johnson RJ, Read G, Isherwood I. Magnetic resonance imaging with Gadolinium-DTPA for assessment of bladder carcinoma and its response to treatment. Clinical Radiology, 1993, 47:302-310.

[11] Zech CJ, Herrmann KA, Reiser MF, Schoenberg SO. MR imaging in patients with suspected liver metastases: value of liver-specific contrast agent Gd-EOB-DTPA. Magnetic resonance in medical sciences, 2007, 6:43-52.

[12] Vander Elst L, Maton F, Laurent S, Seghi F, Chapelle F, Muller RN. A multinuclear MR study of GdEOB-DTPA: Comprehensive preclinical characterization of an organ specific MRI contrast agent. Magnetic Resonance in Medicine, 1997, 38:604-614.

[13] Shimada K, Isoda H, Hirokawa Y, Arizono S, Shibata T, Togashi K. Comparison of gadolinium-EOBDTPA-enhanced and diffusion-weighted liver MRI for detection of small hepatic metastases. European Radiology, 2010, 20:2690-2698.

[14] Clement O, Muhler A, Vexler VS, Kuwatsuru R, Berthezene Y, Rosenau W, Brasch RC. Comparison of Gd-Eob-Dtpa and Gd-Dtpa for Contrast-Enhanced Mr-Imaging of Liver-Tumors. Journal of Magnetic Resonance Imaging, 1993, 3:71-77.

[15] Tyeklar Z, Dunham SU, Midelfort K, Scott DM, Sajiki H, Ong K, Lauffer RB, Caravan P, McMurry TJ. Structural, kinetic, and thermodynamic characterization of the interconverting isomers of MS-325, a gadolinium(III)-based magnetic resonance angiography contrast agent. Inorganic Chemistry, 2007, 46:6621-6631.

[16] TyeklÂAir Z, Dunham SU, Midelfort K, Scott DM, Sajiki H, Ong K, Lauffer RB, Caravan P, McMurry TJ. Structural, kinetic, and thermodynamic characterization of the interconverting isomers of MS-325, a gadolinium(111)-based magnetic resonance angiography contrast agent. Inorganic Chemistry, 2007, 46:6621-6631.

[17] Caravan P, Cloutier NJ, Greenfield MT, McDermid SA, Dunham SU, Bulte JWM, Amedio J, Looby RJ, Supkowski RM, Horrocks J, McMurry TJ, Lauffer RB. The interaction of MS-325 with human serum albumin and its effect on proton relaxation rates. Journal of the American Chemical Society, 2002, 124:3152-3162.

[18] Caravan P, Parigi G, Chasse JM, Cloutier NJ, Ellison JJ, Lauffer RB, Luchinat C, McDermid SA, Spiller M, McMurry TJ. Albumin binding, relaxivity, and water exchange kinetics of the diastereoisomers of MS-325, a gadolinium(III)-based magnetic resonance angiography contrast agent. Inorganic Chemistry, 2007, 46:6632-6639.

[19] Turetschek K, Floyd E, Helbich T, Roberts TPL, Shames DM, Wendland MF, Carter WO, Brasch RC. MRI assessment of microvascular characteristics in experimental breast tumors using a new blood pool contrast agent (MS-325) with correlations to histopathology. Journal of Magnetic Resonance Imaging, 2001, 14:237-242.

[20] Chen C, Cohen JS, Myers CE, Sohn M. Paramagnetic metalloporphyrins as potential contrast agents in NMR imaging. FEBS Letters, 1984, 168:70-74.

[21] Galindev O, Dalantai M, Ahn WS, Shim YK. Gadolinium complexes of chlorin derivatives applicable for MRI contrast agents and PDT. Journal of Porphyrins and Phthalocyanines, 2009, 13:823-831.

[22] Sessler JL, Mody TD, Hemmi GW, Lynch V, Young SW, Miller RA. Gadolinium(III) texaphyrin: A novel MRI contrast agent. Journal of the American Chemical Society, 1993, 115:10366-10367.

[23] Hashemy SI, Ungerstedt JS, Zahedi Avval F, Holmgren A. Motexafin gadolinium, a tumor-selective drug targeting thioredoxin reductase and ribonucleotide reductase. Journal of Biological Chemistry, 2006, 281:10691-10697.

[24] Richards GM, Mehta MP. Motexafin gadolinium in the treatment of brain metastases. Expert Opinion on Pharmacotherapy, 2007, 8:351-359.

[25] Park JA, Lee JJ, Jung JC, Yu DY, Oh C, Ha S, Kim TJ, Chang Y. Gd-DOTA conjugate of RGD as a potential tumor-targeting MRI contrast agent. Chembiochem, 2008, 9:2811-2813.

[26] Zhang W, Chen Y, Guo DJ, Huang ZW, Cai L, He L. The synthesis of a d-glucosamine contrast agent, Gd-DTPA-DG, and its application in cancer molecular imaging with MRI. European Journal of Radiology, 2011, 79:369-374. 
[27] Sukerkar PA, MacRenaris KW, Meade TJ, Burdette JE. A steroid-conjugated magnetic resonance probe enhances contrast in progesterone receptor expressing organs and tumors in vivo. Molecular Pharmaceutics, 2011, 8:1390-1400.

[28] Pais A, Gunanathan C, Margalit R, Biton IE, Yosepovich A, Milstein D, Degani H. In Vivo magnetic resonance imaging of the estrogen receptor in an orthotopic model of human breast cancer. Cancer Research, 2011, 71:7387-7397.

[29] Greish K. Enhanced permeability and retention (EPR) effect for anticancer nanomedicine drug targeting. Methods in molecular biology, 2010, 624:25-37.

[30] Unger EC, Fritz TA, Tilcock C, New TE. Clearance of liposomal gadolinium: in vivo decomplexation. Journal of magnetic resonance imaging, 1991, 1:689-693.

[31] Nwe K, Bryant LH, Brechbiel MW. Poly(amidoamine) Dendrimer Based MRI Contrast Agents Exhibiting Enhanced Relaxivities Derived via Metal Preligation Techniques. Bioconjugate Chemistry, 2010, 21:1014-1017.

[32] Floyd WC, Klemm PJ, Smiles DE, Kohlgruber AC, Pierre VC, Mynar JL, Frechet JMJ, Raymond KN. Conjugation Effects of Various Linkers on Gd(III) MRI Contrast Agents with Dendrimers: Optimizing the Hydroxypyridinonate (HOPO) Ligands with Nontoxic, Degradable Esteramide (EA) Dendrimers for High Relaxivity. Journal of the American Chemical Society, 2011, 133:2390-2393.

[33] Yang JJ, Yang JH, Wei LX, Zurkiya O, Yang W, Li SY, Zou J, Zhou YB, Maniccia ALW, Mao H, Zhao FQ, Malchow R, Zhao SM, Johnson J, Hu XP, Krogstad E, Liu ZR. Rational design of protein-based MRI contrast agents. Journal of the American Chemical Society, 2008, 130:9260-9267.

[34] Caravan P. Protein-Targeted Gadolinium-Based Magnetic Resonance Imaging (MRI) Contrast Agents: Design and Mechanism of Action. Accounts of Chemical Research, 2009, 42:851-862.

[35] Opsahl LR, Uzgiris EE, Vera DR. Tumor Imaging with A Macromolecular Paramagnetic Contrast Agent - Gadopentetate Dimeglumine-Polylysine. Academic Radiology, 1995, 2:762-767.

[36] Yan GP, Liu ML, Li LY. Polyaspartamide gadolinium complexes containing sulfadiazine groups as potential macromolecular MRI contrast agents. Bioconjugate Chemistry, 2005, 16:967-971.

[37] Ye FR, Ke TY, Jeong EK, Wang XL, Sung YG, Johnson M, Lu ZR. Noninvasive visualization of in vivo drug delivery of poly(L-glutamic acid) using contrast-enhanced MRI. Molecular Pharmaceutics, 2006, 3:507-515.

[38] Sirlin CB, Vera DR, Corbeil JA, Caballero MB, Buxton RB, Mattrey RF. Gadolinium-DTPA-dextran: A macromolecular MR blood pool contrast agent. Academic Radiology, 2004, 11:1361-1369.

[39] Helbich TH, Gossman A, Mareski PA, Raduchel B, Roberts TPL, Shames DM, Muhler M, Turetschek $\mathrm{K}$, Brasch RC. A new polysaccharide macromolecular contrast agent for MR imaging: Biodistribution and imaging characteristics. Journal of Magnetic Resonance Imaging, 2000, 11:694-701.

[40] Vera DR, Buonocore MH, Wisner ER, Katzberg RW, Stadalnik RC. A Molecular Receptor-Binding Contrast Agent for Magnetic-Resonance-Imaging of the Liver. Academic Radiology, 1995, 2:497-506.

[41] Andre JP, Geraldes CFGC, Martins JA, Merbach AE, Prata MIM, Santos AC, de Lima JJP, Toth E. Lanthanide(III) complexes of DOTA-glycoconjugates: A potential new class of lectin-mediated medical imaging agents. Chemistry, 2004, 10:5804-5816.

[42] Baia P, Andre JP, Geraldes CFGC, Martins JA, Merbach AE, Toth T. Lanthanide(III) chelates of DTPA bis(amide) glycoconjugates: Potential imaging agents targeted at the asyaloglycoprotein receptor. European Journal of Inorganic Chemistry, 2005, 2110-2119.

[43] Laus S, Sour A, Ruloff R, Toth E, Merbach AE. Rotational dynamics account for pH-dependent relaxivities of PAMAM dendrimeric, Gd-based potential MRI contrast agents. Chemistry, 2005, 11:3064-3076.

[44] Laus S, Ruloff R, Toth E, Merbach AE. Gd-III complexes with fast water exchange and high thermodynamic stability: Potential building blocks for high-relaxivity MRI contrast agents. Chemistry; 2003, 9:3555-3566.

[45] Rudovsky J, Kotek J, Hermann P, Lukes I, Mainero V, Aime S. Synthesis of a bifunctional monophosphinic acid DOTA analogue ligand and its lanthanide(III) complexes. A gadolinium(III) 
complex endowed with an optimal water exchange rate for MRI applications. Organic \& Biomolecular Chemistry, 2005, 3:112-117.

[46] Ali MM, Woods M, Caravan P, Opina ACL, Spiller M, Fettinger JC, Sherry AD. Synthesis and relaxometric studies of a dendrimer-based pH-responsive MRI contrast agent. Chemistry, 2008, 14:7250-7258.

[47] Sato N, Kobayashi H, Hiraga A, Saga T, Togashi K, Konishi J, Brechbiel MW. Pharmacokinetics and enhancement patterns of macromolecular MR contrast agents with various sizes of polyamidoamine dendrimer cores. Magnetic Resonance in Medicine, 2001, 46:1169-1173.

[48] Kobayashi H, Kawamoto S, Star RA, Waldmann TA, Tagaya Y, Brechbiel MW. Micro-magnetic resonance lymphangiography in mice using a novel dendrimer-based magnetic resonance imaging contrast agent. Cancer Research, 2003, 63:271-276.

[49] Kobayashi H, Kawamoto S, Star RA, Waldmann TA, Brechbiel MW, Choyke PL. Activated clearance of a biotinylated macromolecular MRI contrast agent from the blood pool using an avidin chase. Bioconjugate Chemistry, 2003, 14:1044-1047.

[50] Yordanov AT, Kobayashi H, English SJ, Reijnders K, Milenic D, Krishna MC, Mitchell JB, Brechbiel MW. Gadolinium-labeled dendrimers as biometric nanoprobes to detect vascular permeability. Journal of Materials Chemistry, 2003, 13:1523-1525.

[51] Cyran CC, Fu YJ, Raatschen HJ, Rogut V, Chaopathomkul B, Shames DM, Wendland MF, Yeh BM, Brasch RC. New macromolecular polymeric MRI contrast agents for application in the differentiation of cancer from benign soft tissues. Journal of Magnetic Resonance Imaging, 2008, 27:581-589.

[52] Kojima C, Turkbey B, Ogawa M, Bernardo M, Regino CAS, Bryant LH, Choyke PL, Kono K, Kobayashi H. Dendrimer-based MRI contrast agents: The effects of PEGylation on relaxivity and pharmacokinetics. Nanomedicine: Nanotechnology, Biology, and Medicine, 2011, 7:1001-1008.

[53] Luo K, Liu G, She W, Wang Q, Wang G, He B, Ai H, Gong Q, Song B, Gu Z. Gadolinium-labeled peptide dendrimers with controlled structures as potential magnetic resonance imaging contrast agents. Biomaterials, 2011, 32:7951-7960.

[54] Nwe K, Milenic DE, Ray GL, Kim YS, Brechbiel MW. Preparation of cystamine core dendrimer and antibody - Dendrimer conjugates for MRI angiography. Molecular Pharmaceutics, 2012, 9:374-381.

[55] Kobayashi H, Sato N, Saga T, Nakamoto Y, Ishimori T, Toyama S, Togashi K, Konishi J, Brechbiel MW. Monoclonal antibody-dendrimer conjugates enable radiolabeling of antibody with markedly high specific activity with minimal loss of immunoreactivity. European Journal of Nuclear Medicine, 2000, 27:1334-1339.

[56] Konda SD, Aref M, Brechbiel M, Wiener EC. Development of a tumor-targeting MR contrast agent using the high- affinity folate receptor: Work in progress. Investigative Radiology, 2000, 35:50-57.

[57] Konda SD, Wang S, Brechbiel M, Wiener EC. Biodistribution of a 153Gd-folate dendrimer, generation $=4$, in mice with folate-receptor positive and negative ovarian tumor xenografts. Investigative Radiology, 2002, 37:199-204.

[58] Konda SD, Aref M, Wang S, Brechbiel M, Wiener EC. Specific targeting of folate-dendrimer MRI contrast agents to the high affinity folate receptor expressed in ovarian tumor xenografts. Magnetic Resonance Materials in Physics, Biology and Medicine, 2001, 12:104-113.

[59] Wiener EC, Konda S, Shadron A, Brechbiel M, Gansow O. Targeting dendrimer-chelates to tumors and tumor cells expressing the high-affinity folate receptor. Investigative Radiology, 1997, 32:748-754.

[60] Boswell CA, Eck PK, Regino CAS, Bernardo M, Wong KJ, Milenic DE, Choyke PL, Brechbiel MW. Synthesis, characterization, and biological evaluation of integrin alphavbeta 3-targeted PAMAM dendrimers. Molecular Pharmaceutics, 2008, 5:527-539.

[61] Cheng ZL, Thorek DLJ, Tsourkas A. Gadolinium-Conjugated Dendrimer Nanoclusters as a TumorTargeted T-1 Magnetic Resonance Imaging Contrast Agent. Angewandte Chemie International Edition, 2010, 49:346-350. 
[62] Miyake, Y., Kimura, Y., Ishikawa, S., Tsujita, H., Miura, H., Narazaki, M., Matsuda, T., Tabata, Y., Yano, T., Toshimitsu, A., and Kondo, T. Synthesis and functional evaluation of chiral dendrimertriamine-coordinated Gd complexes as highly sensitive MRI contrast agents. Tetrahedron Letters, 2012, 53(34):4580-4583.

[63] Klemm PJ, Floyd WC, Smiles DE, FrÃ chet JMJ, Raymond KN. Improving T1 and T2 magnetic resonance imaging contrast agents through the conjugation of an esteramide dendrimer to high-watercoordination Gd(III) hydroxypyridinone complexes. Contrast Media and Molecular Imaging, 2012, 7:95-99.

[64] Schmiedl U, Ogan MD, Moseley ME, Brasch RC. Comparison of the contrast-enhancing properties of albumin-(Gd-DTPA) and Gd-DTPA at 2.0 T: An experimental study in rats. American Journal of Roentgenology, 1986, 147:1263-1270.

[65] Lauffer RB, Brady TJ. Preparation and water relaxation properties of proteins labeled with paramagnetic metal chelates. Magnetic Resonance Imaging, 1985, 3:11-16.

[66] Paajanen H, Reisto T, Hemmila I, Komu M, Niemi P, Kormano M. Proton relaxation enhancement of albumin, immunoglobulin G, and fibrinogen labeled with Gd-DTPA. Magnetic Resonance in Medicine, 1990, 13:38-43.

[67] Wikstrom MG, Moseley ME, White DL, Dupon JW, Winkelhake JL, Kopplin J, Brasch RC. Contrastenhanced MRI of tumors. Comparison of Gd-DTPA and a macromolecular agent. Investigative Radiology, 1989, 24:609-615.

[68] Daldrup H, Shames DM, Wendland M, Okuhata Y, Link TM, Rosenau W, Lu Y, Brasch RC. Correlation of dynamic contrast-enhanced MR imaging with histologic tumor grade: Comparison of macromolecular and small-molecular contrast media. American Journal of Roentgenology, 1998, 171:941-949.

[69] Gossmann A, Okuhata Y, Shames DM, Helbich TH, Roberts TPL, Wendland MF, Huber S, Brasch RC. Prostate cancer tumor grade differentiation with dynamic contrast- enhanced MR imaging in the rat: Comparison of macromolecular and small- molecular contrast media - Preliminary experience. Radiology, 1999, 213:265-272.

[70] Van Dijke CF, Brasch RC, Roberts TPL, Weidner N, Mathur A, Shames DM, Mann JS, Demsar F, Lang P, Schwickert HC. Mammary carcinoma model: Correlation of macromolecular contrastenhanced MR imaging characterizations of tumor microvasculature and histologic capillary density. Radiology, 1996, 198:813-818.

[71] Turetschek K, Huber S, Floyd E, Helbich T, Roberts TPL, Shames DM, Tarlo KS, Wendland MF, Brasch RC. MR imaging characterization of microvessels in experimental breast tumors by using a particulate contrast agent with histopathologic correlation. Radiology, 2001, 218:562-569.

[72] Aicher KP, Dupon JW, White DL, Aukerman SL, Moseley ME, Juster R, Rosenau W, Winkelhake JL, Brasch RC. Contrast-enhanced magnetic resonance imaging of tumor-bearing mice treated with human recombinant tumor necrosis factor alpha. Cancer Research, 1990, 50:7376-7381.

[73] Schwickert HC, Stiskal M, Roberts TPL, Van Dijke CF, Mann J, MÃ1/4hler A, Shames DM, Demsar F, Disston A, Brasch RC. Contrast-enhanced MR imaging assessment of tumor capillary permeability: Effect of irradiation on delivery of chemotherapy. Radiology, 1996, 198:893-898.

[74] Murad GJA, Walbridge S, Morrison PF, Garmestani K, Degen JW, Brechbiel MW, Oldfield EH, Lonser RR. Real-time, image-guided, convection-enhanced delivery of interleukin 13 bound to Pseudomonas exotoxin. Clinical Cancer Research, 2006, 12:3145-3151.

[75] Krishnan AS, Neves AA, De Backer MM, Hu DE, Davletov B, Kettunen MI, Brindle KM. Detection of cell death in tumors by using MR imaging and a gadolinium-based targeted contrast agent. Radiology, 2008, 246:854-862.

[76] Artemov D, Mori N, Ravi R, Bhujwalla ZM. Magnetic resonance molecular imaging of the HER2/neu receptor. Cancer Research, 2003, 63:2723-2727.

[77] Shahbazi-Gahrouei D, Rizvi SM, Williams MA, Allen BJ. In vitro studies of gadolinium-DTPA conjugated with monoclonal antibodies as cancer-specific magnetic resonance imaging contrast agents. Australasian Physical and Engineering Sciences in Medicine, 2002, 25:31-38. 
[78] Shahbazi-Gahrouei D, Williams M, Rizvi S, Allen BJ. In vivo studies of Gd-DTPA-monoclonal antibody and Gd-porphyrins: Potential magnetic resonance imaging contrast agents for melanoma. Journal of Magnetic Resonance Imaging, 2001, 14:169-174.

[79] Kuriu Y, Otsuji E, Kin S, Nakase Y, Fukuda KI, Okamoto K, Hagiwara A, Yamagishi H. Monoclonal antibody conjugated to gadolinium as a contrast agent for magnetic resonance imaging of human rectal carcinoma. Journal of Surgical Oncology, 2006, 94:144-148.

[80] Curtet C, Tellier C, Bohy J. Selective modification of NMR relaxation time in human colorectal carcinoma by using gadolinium diethylenetriaminepentaacetic acid conjugated with monoclonal antibody 19-9. Proceedings of the National Academy of Sciences of the United States of America, 1986, 83:4277-4281.

[81] Curtet C, Bourgoin C, Bohy J, Saccavini JC, Thedrez P, Akoka S, Tellier C, Chatal JF. Gd-25 DTPA$\mathrm{MAb}$, a potential NMR contrast agent for MRI in the xenografted nude mouse: Preliminary studies. International Journal of Cancer, 1988, 41:126-132.

[82] Unger EC, Totty WG, Neufeld DM. Magnetic resonance imaging using gadolinium labeled monoclonal antibody. Investigative Radiology, 1985, 20:693-700.

[83] Anderson-Berg WT, Strand M, Lempert TE. Nuclear magnetic resonance and gamma camera tumor imaging using gadolinium-labeled monoclonal antibodies. Journal of Nuclear Medicine, 1986, 27:829-833.

[84] Ratzinger G, Agrawal P, Körner W, Lonkai J, Sanders HMHF, Terreno E, Wirth M, Strijkers GJ, Nicolay K, Gabor F. Surface modification of PLGA nanospheres with Gd-DTPA and Gd-DOTA for high-relaxivity MRI contrast agents. Biomaterials, 2010, 31:8716-8723.

[85] Shiraishi K, Kawano K, Minowa T, Maitani Y, Yokoyama M. Preparation and in vivo imaging of PEGpoly(L-lysine)-based polymeric micelle MRI contrast agents. Journal of Controlled Release, 2009, 136:14-20.

[86] Nakamura E, Makino K, Okano T, Yamamoto T, Yokoyama M. A polymeric micelle MRI contrast agent with changeable relaxivity. Journal of Controlled Release, 2006, 114:325-333.

[87] Shiraishi K, Kawano K, Maitani Y, Yokoyama M. Polyion complex micelle MRI contrast agents from poly(ethylene glycol)-b-poly(l-lysine) block copolymers having Gd-DOTA; preparations and their control of T 1-relaxivities and blood circulation characteristics. Journal of Controlled Release, 2010, 148:160-167.

[88] Kaida S, Cabral H, Kumagai M, Kishimura A, Terada Y, Sekino M, Aoki I, Nishiyama N, Tani T, Kataoka K. Visible Drug Delivery by Supramolecular Nanocarriers Directing to Single-Platformed Diagnosis and Therapy of Pancreatic Tumor Model. Cancer Research, 2010, 70:7031-7041.

[89] Li X, Qian Y, Liu T, Hu X, Zhang G, You Y, Liu S. Amphiphilic multiarm star block copolymer-based multifunctional unimolecular micelles for cancer targeted drug delivery and MR imaging. Biomaterials, 2011, 32:6595-6605.

[90] Liao Z, Wang H, Wang X, Zhao P, Wang S, Su W, Chang J. Multifunctional nanoparticles composed of a poly(dl -lactide-coglycolide) core and a paramagnetic liposome shell for simultaneous magnetic resonance imaging and targeted therapeutics. Advanced Functional Materials, 2011, 21:1179-1186.

[91] Liu T, Qian Y, Hu X, Ge Z, Liu S. Mixed polymeric micelles as multifunctional scaffold for combined magnetic resonance imaging contrast enhancement and targeted chemotherapeutic drug delivery. Journal of Materials Chemistry, 2012, 22:5020-5030.

[92] Liu T, Li X, Qian Y, Hu X, Liu S. Multifunctional pH-Disintegrable micellar nanoparticles of asymmetrically functionalized $\hat{\mathrm{I}}^{2}$-cyclodextrin-Based star copolymer covalently conjugated with doxorubicin and DOTA-Gd moieties. Biomaterials, 2012, 33:2521-2531.

[93] Bui T, Stevenson J, Hoekman J, Zhang S, Maravilla K, Ho RJY. Novel Gd nanoparticles enhance vascular contrast for high-resolution magnetic resonance imaging. PLOS ONE, 2010, 5:1-7.

[94] Aime S, Castelli DD, Crich SG, Gianolio E, Terreno E. Pushing the Sensitivity Envelope of Lanthanide-Based Magnetic Resonance Imaging (MRI) Contrast Agents for Molecular Imaging Applications. Accounts of Chemical Research, 2009, 42:822-831. 
[95] Unger EC, Winokur T, MacDougall P, Rosenblum J, Clair M, Gatenby R, Tilcock C. Hepatic metastases: liposomal Gd-DTPA-enhanced MR imaging. Radiology, 1989, 171:81-85.

[96] Li W, Su B, Meng S, Ju L, Yan L, Ding Y, Song Y, Zhou W, Li H, Tang L, Zhao Y, Zhou C. RGDtargeted paramagnetic liposomes for early detection of tumor: In vitro and in vivo studies. European Journal of Radiology, 2011, 80:598-606.

[97] Korotcov A, Shan L, Meng H, Wang T, Sridhar R, Zhao Y, Liang XJ, Wang PC. A nanocomplex system as targeted contrast agent delivery vehicle for magnetic resonance imaging dynamic contrast enhancement study. Journal of Nanoscience and Nanotechnology, 2010, 10:7545-7549.

[98] Ward KM, Aletras AH, Balaban RS. A new class of contrast agents for MRI based on proton chemical exchange dependent saturation transfer (CEST). Journal of Magnetic Resonance, 2000, 143:79-87.

[99] Lin W, Vivero-Escoto JL, Taylor-Pashow KML, Huxford RC, Della Rocca J, Okoruwa C, An H, Lin W. Multifunctional mesoporous silica nanospheres with cleavable Gd(III) chelates as MRI contrast agents: Synthesis, characterization, target-specificity, and renal clearance. Small, 2011, 7:3519-3528.

[100] Shao Y, Tian X, Hu W, Zhang Y, Liu H, He H, Shen Y, Xie F, Li L. The properties of Gd 20 3assembled silica nanocomposite targeted nanoprobes and their application in MRI. Biomaterials, 2012, 33:6438-6446.

[101] Wu Y, Xu X, Tang Q, Li Y. A new type of silica-coated Gd 2(CO 3) 3:Tb nanoparticle as a bifunctional agent for magnetic resonance imaging and fluorescent imaging. Nanotechnology, 2012, 23.

[102] Datta A, Hooker JM, Botta M, Francis MB, Aime S, Raymond KN. High relaxivity gadolinium hydroxypyridonate-viral capsid conjugates: Nanosized MRI contrast agents. Journal of the American Chemical Society, 2008, 130:2546-2552.

[103] Moriggi L, Cannizzo C, Dumas E, Mayer CR, Ulianov A, Helm L. Gold Nanoparticles Functionalized with Gadolinium Chelates as High-Relaxivity MRI Contrast Agents. Journal of the American Chemical Society, 2009, 131:10828-+.

[104] Song Y, Xu XY, MacRenaris KW, Zhang XQ, Mirkin CA, Meade TJ. Multimodal GadoliniumEnriched DNA-Gold Nanoparticle Conjugates for Cellular Imaging. Angewandte ChemieInternational Edition, 2009, 48:9143-9147.

[105] Zhang JF, Fatouros PP, Shu CY, Reid J, Owens LS, Cai T, Gibson HW, Long GL, Corwin FD, Chen ZJ, Dorn HC. High Relaxivity Trimetallic Nitride (Gd3N) Metallofullerene MRI Contrast Agents with Optimized Functionality. Bioconjugate Chemistry, 2010, 21:610-615.

[106] Shu CY, Corwin FD, Zhang JF, Chen ZJ, Reid JE, Sun MH, Xu W, Sim JH, Wang CR, Fatouros PP, Esker AR, Gibson HW, Dorn HC. Facile Preparation of a New Gadofullerene-Based Magnetic Resonance Imaging Contrast Agent with High H-1 Relaxivity. Bioconjugate Chemistry, 2009, 20:1186-1193.

[107] Wang YXJ, Hussain SM, Krestin GP. Superparamagnetic iron oxide contrast agents: physicochemical characteristics and applications in MR imaging. European Radiology, 2001, 11:2319-2331.

[108] Enochs WS, Harsh G, Hochberg F, Weissleder R. Improved delineation of human brain tumors on MR images using a long-circulating, superparamagnetic iron oxide agent. Journal of Magnetic Resonance Imaging, 1999, 9:228-232.

[109] Varallyay P, Nesbit G, Muldoon LL, Nixon RR, Delashaw J, Cohen JI, Petrillo A, Rink D, Neuwelt EA. Comparison of two superparamagnetic viral-sized iron oxide particles ferumoxides and ferumoxtran-10 with a gadolinium chelate in imaging intracranial tumors. American Journal of Neuroradiology, 2002, 23:510-519.

[110] Corot C, Robert P, Idee JM, Port M. Recent advances in iron oxide nanocrystal technology for medical imaging. Advanced Drug Delivery Reviews, 2006, 58:1471-1504.

[111] Sun C, Du K, Fang C, Bhattarai N, Veiseh O, Kievit F, Stephen Z, Lee D, Ellenbogen RG, Ratner B, Zhang M. PEG-mediated synthesis of highly dispersive multifunctional superparamagnetic nanoparticles: their physicochemical properties and function in vivo. ACS Nano, 2010, 4:2402-2410.

[112] Gupta AK, Gupta M. Synthesis and surface engineering of iron oxide nanoparticles for biomedical applications. Biomaterials, 2005, 26:3995-4021. 
[113] Laurent S, Forge D, Port M, Roch A, Robic C, Vander EL, Muller RN. Magnetic iron oxide nanoparticles: synthesis, stabilization, vectorization, physicochemical characterizations, and biological applications. Chemical Review, 2008, 108:2064-2110.

[114] Choi HS, Liu W, Misra P, Tanaka E, Zimmer JP, Itty IB, Bawendi MG, Frangioni JV. Renal clearance of quantum dots. Nature Biotechnology, 2007, 25:1165-1170.

[115] Weissleder R, Bogdanov A, Neuwelt EA, Papisov M. Long-circulating iron oxides for MR imaging. Advanced Drug Delivery Reviews, 1995, 16:321-334.

[116] Weissleder R, Stark DD, Engelstad BL, Bacon BR, Compton CC, White DL, Jacobs P, Lewis J. Superparamagnetic iron oxide: pharmacokinetics and toxicity. American Journal of Roentgenol, 1989 , 152:167-173.

[117] Lin WB, Hyeon T, Lanza GM, Zhang MQ, Meade TJ. Magnetic Nanoparticles for Early Detection of Cancer by Magnetic Resonance Imaging. Mrs Bulletin, 2009, 34:441-448.

[118] Saini S, Stark DD, Hahn PF, Bousquet JC, Introcasso J, Wittenberg J, Brady TJ, Ferrucci JT, Jr. Ferrite particles: a superparamagnetic MR contrast agent for enhanced detection of liver carcinoma. Radiology, 1987, 162:217-222.

[119] Saini S, Stark DD, Hahn PF, Bousquet JC, Introcasso J, Wittenberg J, Brady TJ, Ferrucci JT, Jr. Ferrite particles: a superparamagnetic MR contrast agent for enhanced detection of liver carcinoma. Radiology, 1987, 162:217-222.

[120] Stark DD, Weissleder R, Elizondo G, Hahn PF, Saini S, Todd LE, Wittenberg J, Ferrucci JT. Superparamagnetic iron oxide: clinical application as a contrast agent for MR imaging of the liver. Radiology, 1988, 168:297-301.

[121] Reimer P, Jahnke N, Fiebich M, Schima W, Deckers F, Marx C, Holzknecht N, Saini S. Hepatic lesion detection and characterization: value of nonenhanced MR imaging, superparamagnetic iron oxideenhanced MR imaging, and spiral CT-ROC analysis. Radiology, 2000, 217:152-158.

[122] Weissleder R, Hahn PF, Stark DD, Elizondo G, Saini S, Todd LE, Wittenberg J, Ferrucci JT. Superparamagnetic Iron-Oxide - Enhanced Detection of Focal Splenic Tumors with Mr Imaging. Radiology, 1988, 169:399-403.

[123] Laurent S, Forge D, Port M, Roch A, Robic C, Vander EL, Muller RN. Magnetic iron oxide nanoparticles: synthesis, stabilization, vectorization, physicochemical characterizations, and biological applications. Chemical Reviews, 2008, 108:2064-2110.

[124] Neuberger T, Schopf B, Hofmann H, Hofmann M, von Rechenberg B. Superparamagnetic nanoparticles for biomedical applications: Possibilities and limitations of a new drug delivery system. Journal of Magnetism and Magnetic Materials, 2005, 293:483-496.

[125] Anzai Y, Piccoli CW, Outwater EK, Stanford W, Bluemke DA, Nurenberg P, Saini S, Maravilla KR, Feldman DE, Schmiedl UP, Brunberg JA, Francis IR, Harms SE, Som PM, Tempany CM. Evaluation of neck and body metastases to nodes with ferumoxtran 10-enhanced MR imaging: phase III safety and efficacy study. Radiology, 2003, 228:777-788.

[126] McCarthy JR, Weissleder R. Multifunctional magnetic nanoparticles for targeted imaging and therapy. Advanced Drug Delivery Reviews, 2008, 60:1241-1251.

[127] Harisinghani MG, Barentsz J, Hahn PF, Deserno WM, Tabatabaei S, van de Kaa CH, de la RJ, Weissleder R. Noninvasive detection of clinically occult lymph-node metastases in prostate cancer. The New England Journal of Medicine, 2003, 348:2491-2499.

[128] Harisinghani MG, Jhaveri KS, Weissleder R, Schima W, Saini S, Hahn PF, Mueller PR. MRI contrast agents for evaluating focal hepatic lesions. Clinical Radiology, 2001, 56:714-725.

[129] Harisinghani MG, Saini S, Weissleder R, Halpern EF, Schima W, Rubin DL, Stillman AE, Sica GT, Small WC, Hahn PF. Differentiation of liver hemangiomas from metastases and hepatocellular carcinoma at MR imaging enhanced with blood-pool contrast agent Code-7227. Radiology, 1997, 202:687-691.

[130] Tassa C, Shaw SY, Weissleder R. Dextran-coated iron oxide nanoparticles: a versatile platform for targeted molecular imaging, molecular diagnostics, and therapy. Accounts of Chemical Research, 2011, 44:842-852. 
[131] Teja AS, Koh PY. Synthesis, properties, and applications of magnetic iron oxide nanoparticles. Progress in Crystal Growth and Characterization of Materials, 2009, 55:22-45.

[132] Massart R. Preparation of Aqueous Magnetic Liquids in Alkaline and Acidic Media. IEEE Transactions on Magnetics, 1981, 17:1247-1248.

[133] Gupta AK, Gupta M. Synthesis and surface engineering of iron oxide nanoparticles for biomedical applications. Biomaterials, 2005, 26:3995-4021.

[134] Sun SH, Zeng H, Robinson DB, Raoux S, Rice PM, Wang SX, Li GX. Monodisperse MFe2O4 (M = $\mathrm{Fe}, \mathrm{Co}, \mathrm{Mn}$ ) nanoparticles. Journal of the American Chemical Society, 2004, 126:273-279.

[135] Lee JH, Huh YM, Jun Y, Seo J, Jang J, Song HT, Kim S, Cho EJ, Yoon HG, Suh JS, Cheon J. Artificially engineered magnetic nanoparticles for ultra-sensitive molecular imaging. Nature Medicine, 2007, 13:95-99.

[136] Tassa C, Shaw SY, Weissleder R. Dextran-coated iron oxide nanoparticles: a versatile platform for targeted molecular imaging, molecular diagnostics, and therapy. Accounts of Chemical Research, 2011, 44:842-852.

[137] Laurent S, Forge D, Port M, Roch A, Robic C, Vander EL, Muller RN. Magnetic iron oxide nanoparticles: synthesis, stabilization, vectorization, physicochemical characterizations, and biological applications. Chemical Reviews, 2008, 108:2064-2110.

[138] Gupta AK, Wells S. Surface-modified superparamagnetic nanoparticles for drug delivery: preparation, characterization, and cytotoxicity studies. IEEE Trans Nanobioscience, 2004, 3:66-73.

[139] Gupta AK, Curtis AS. Surface modified superparamagnetic nanoparticles for drug delivery: interaction studies with human fibroblasts in culture. Journal of Materials Science: Materials in Medicine, 2004, $15: 493-496$.

[140] Kohler N, Fryxell GE, Zhang M. A bifunctional poly(ethylene glycol) silane immobilized on metallic oxide-based nanoparticles for conjugation with cell targeting agents. Journal of American Chemical Society, 2004, 126:7206-7211.

[141] Lee H, Yu MK, Park S, Moon S, Min JJ, Jeong YY, Kang HW, Jon S. Thermally cross-linked superparamagnetic iron oxide nanoparticles: synthesis and application as a dual imaging probe for cancer in vivo. Journal of American Chemical Society, 2007, 129:12739-12745.

[142] Amstad E, Zurcher S, Mashaghi A, Wong JY, Textor M, Reimhult E. Surface functionalization of single superparamagnetic iron oxide nanoparticles for targeted magnetic resonance imaging. Small, 2009, 5:1334-1342.

[143] Nasongkla N, Bey E, Ren J, Ai H, Khemtong C, Guthi JS, Chin SF, Sherry AD, Boothman DA, Gao J. Multifunctional polymeric micelles as cancer-targeted, MRI-ultrasensitive drug delivery systems. Nano Letters, 2006, 6:2427-2430.

[144] Lee H, Yu MK, Park S, Moon S, Min JJ, Jeong YY, Kang HW, Jon S. Thermally cross-linked superparamagnetic iron oxide nanoparticles: synthesis and application as a dual imaging probe for cancer in vivo. Journal of American Chemical Society, 2007, 129:12739-12745.

[145] Amstad E, Zurcher S, Mashaghi A, Wong JY, Textor M, Reimhult E. Surface functionalization of single superparamagnetic iron oxide nanoparticles for targeted magnetic resonance imaging. Small, 2009, 5:1334-1342.

[146] Nasongkla N, Bey E, Ren J, Ai H, Khemtong C, Guthi JS, Chin SF, Sherry AD, Boothman DA, Gao J. Multifunctional polymeric micelles as cancer-targeted, MRI-ultrasensitive drug delivery systems. Nano Letters, 2006, 6:2427-2430.

[147] Laurent S, Forge D, Port M, Roch A, Robic C, Vander EL, Muller RN. Magnetic iron oxide nanoparticles: synthesis, stabilization, vectorization, physicochemical characterizations, and biological applications. Chemical Reviews, 2008, 108:2064-2110.

[148] Lu Y, Yin YD, Mayers BT, Xia YN. Modifying the surface properties of superparamagnetic iron oxide nanoparticles through a sol-gel approach. Nano Letters, 2002, 2:183-186.

[149] Kim J, Kim HS, Lee N, Kim T, Kim H, Yu T, Song IC, Moon WK, Hyeon T. Multifunctional uniform nanoparticles composed of a magnetite nanocrystal core and a mesoporous silica shell for magnetic 
resonance and fluorescence imaging and for drug delivery. Angewandte Chemie Internationl Edition, 2008, 47:8438-8441.

[150] Liu Q, Zhang J, Xia W, Gu H. Magnetic field enhanced cell uptake efficiency of magnetic silica mesoporous nanoparticles. Nanoscale, 2012, 4:3415-3421.

[151] McCarthy JR, Weissleder R. Multifunctional magnetic nanoparticles for targeted imaging and therapy. Advanced Drug Delivery Reviews, 2008, 60:1241-1251.

[152] Tassa C, Shaw SY, Weissleder R. Dextran-coated iron oxide nanoparticles: a versatile platform for targeted molecular imaging, molecular diagnostics, and therapy. Accounts of Chemical Research, 2011, 44:842-852.

[153] Laurent S, Forge D, Port M, Roch A, Robic C, Vander EL, Muller RN. Magnetic iron oxide nanoparticles: synthesis, stabilization, vectorization, physicochemical characterizations, and biological applications. Chemical Reviews, 2008, 108:2064-2110.

[154] Weissleder R, Kelly K, Sun EY, Shtatland T, Josephson L. Cell-specific targeting of nanoparticles by multivalent attachment of small molecules. Nature Biotechnology, 2005, 23:1418-1423.

[155] Leimgruber A, Berger C, Cortez-Retamozo V, Etzrodt M, Newton A, Waterman P, Figueiredo JL, Kohler R, Elpek N, Mempel TR, Swirski FK, Nahrendorf M, Weissleder R, Pittet MJ. Behavior of Endogenous Tumor-Associated Macrophages Assessed In Vivo Using a Functionalized Nanoparticle. Neoplasia, 2009, 11:459-U58.

[156] Weissleder R, Kelly K, Sun EY, Shtatland T, Josephson L. Cell-specific targeting of nanoparticles by multivalent attachment of small molecules. Nature Biotechnology, 2005, 23:1418-1423.

[157] Tsourkas A, Shinde-Patil VR, Kelly KA, Patel P, Wolley A, Allport JR, Weissleder R. In vivo imaging of activated endothelium using an anti-VCAM-1 magnetooptical probe. Bioconjugate Chemistry, 2005, 16:576-581.

[158] Kelly KA, Allport JR, Tsourkas A, Shinde-Patil VR, Josephson L, Weissleder R. Detection of vascular adhesion molecule-1 expression using a novel multimodal nanoparticle. Circulation Research, 2005, 96:327-336.

[159] Kelly KA, Nahrendorf M, Yu AM, Reynolds F, Weissleder R. In vivo phage display selection yields atherosclerotic plaque targeted peptides for imaging. Molecular Imaging and Biology, 2006, 8:201-207.

[160] Nahrendorf M, Jaffer FA, Kelly KA, Sosnovik DE, Aikawa E, Libby P, Weissleder R. Noninvasive vascular cell adhesion molecule-1 imaging identifies inflammatory activation of cells in atherosclerosis. Circulation, 2006, 114:1504-1511.

[161] Choi H, Choi SR, Zhou R, Kung HF, Chen IW. Iron oxide nanoparticles as magnetic resonance contrast agent for tumor imaging via folate receptor-targeted delivery. Academic Radiology, 2004, 11:996-1004.

[162] Chen TJ, Cheng TH, Hung YC, Lin KT, Liu GC, Wang YM. Targeted folic acid-PEG nanoparticles for noninvasive imaging of folate receptor by MRI. Journal of Biomedical Materials Research A, 2008, 87:165-175.

[163] Kresse M, Wagner S, Pfefferer D, Lawaczeck R, Elste V, Semmler W. Targeting of ultrasmall superparamagnetic iron oxide (USPIO) particles to tumor cells in vivo by using transferrin receptor pathways. Magnetic Resonance in Medicine, 1998, 40:236-242.

[164] Xie J, Chen K, Lee HY, Xu C, Hsu AR, Peng S, Chen X, Sun S. Ultrasmall c(RGDyK)-coated Fe3O4 nanoparticles and their specific targeting to integrin alpha(v)beta3-rich tumor cells. Journal of American Chemical Society, 2008, 130:7542-7543.

[165] Lin RY, Dayananda K, Chen TJ, Chen CY, Liu GC, Lin KL, Wang YM. Targeted RGD nanoparticles for highly sensitive in vivo integrin receptor imaging. Contrast Media \& Molecular Imaging, 2012, 7:7-18.

[166] McIntyre DJO, Madhu B, Lee SH, Griffiths JR. Magnetic Resonance Spectroscopy of Cancer Metabolism and Response to Therapy. Radiation Research, 2012, 177:398-435. 
[167] Zhao M, Beauregard DA, Loizou L, Davletov B, Brindle KM. Non-invasive detection of apoptosis using magnetic resonance imaging and a targeted contrast agent. Nature Medicine, 2001, 7:1241-1244.

[168] Neves AA, Krishnan AS, Kettunen MI, Hu DE, de Backer MM, Davletov B, Brindle KM. A paramagnetic nanoprobe to detect tumor cell death using magnetic resonance imaging. Nano Letters, 2007, 7:1419-1423.

[169] De Leon-Rodriguez LM, Lubag AJ, Malloy CR, Martinez GV, Gillies RJ, Sherry AD. Responsive MRI agents for sensing metabolism in vivo. Accounts of Chemical Research, 2009, 42:948-957.

[170] Iwaki S, Hanaoka K, Piao W, Komatsu T, Ueno T, Terai T, Nagano T. Development of hypoxiasensitive Gd3+-based MRI contrast agents. Bioorganic \& Medicinal Chemistry Letters, 2012, 22:2798-2802. 



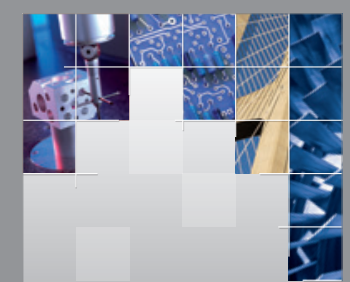

\section{Enfincering}
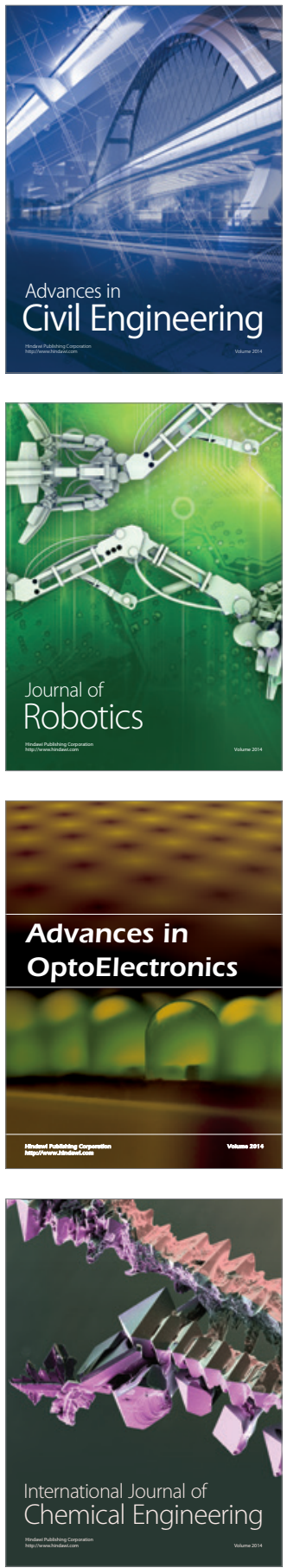

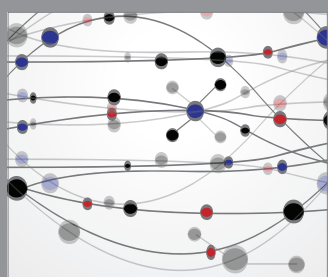

The Scientific World Journal

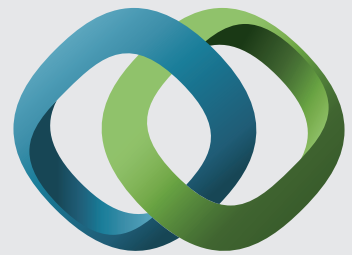

\section{Hindawi}

Submit your manuscripts at

http://www.hindawi.com
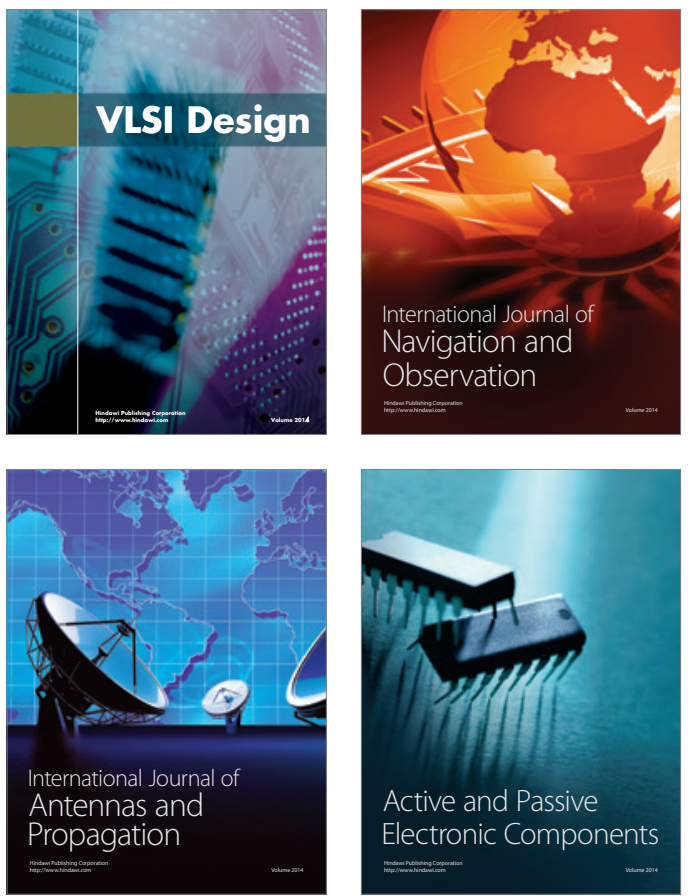
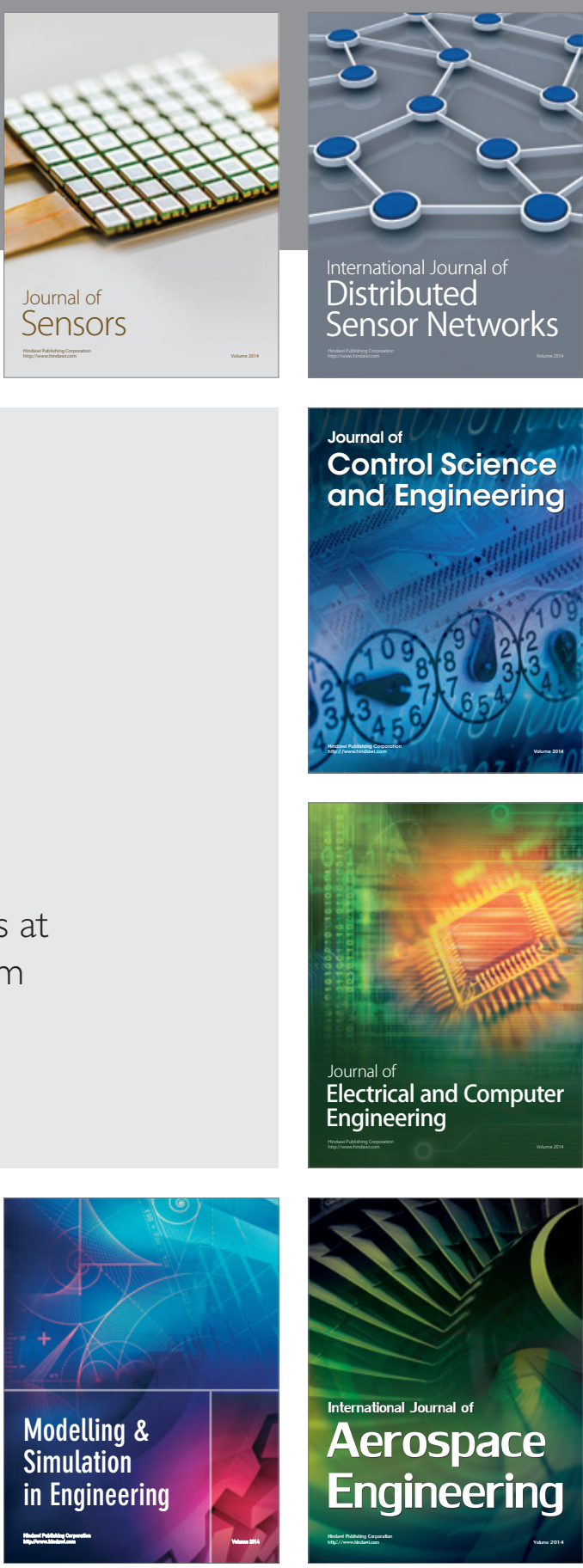

International Journal of

Distributed

Sensor Networks

Journal of

Control Science

and Engineering
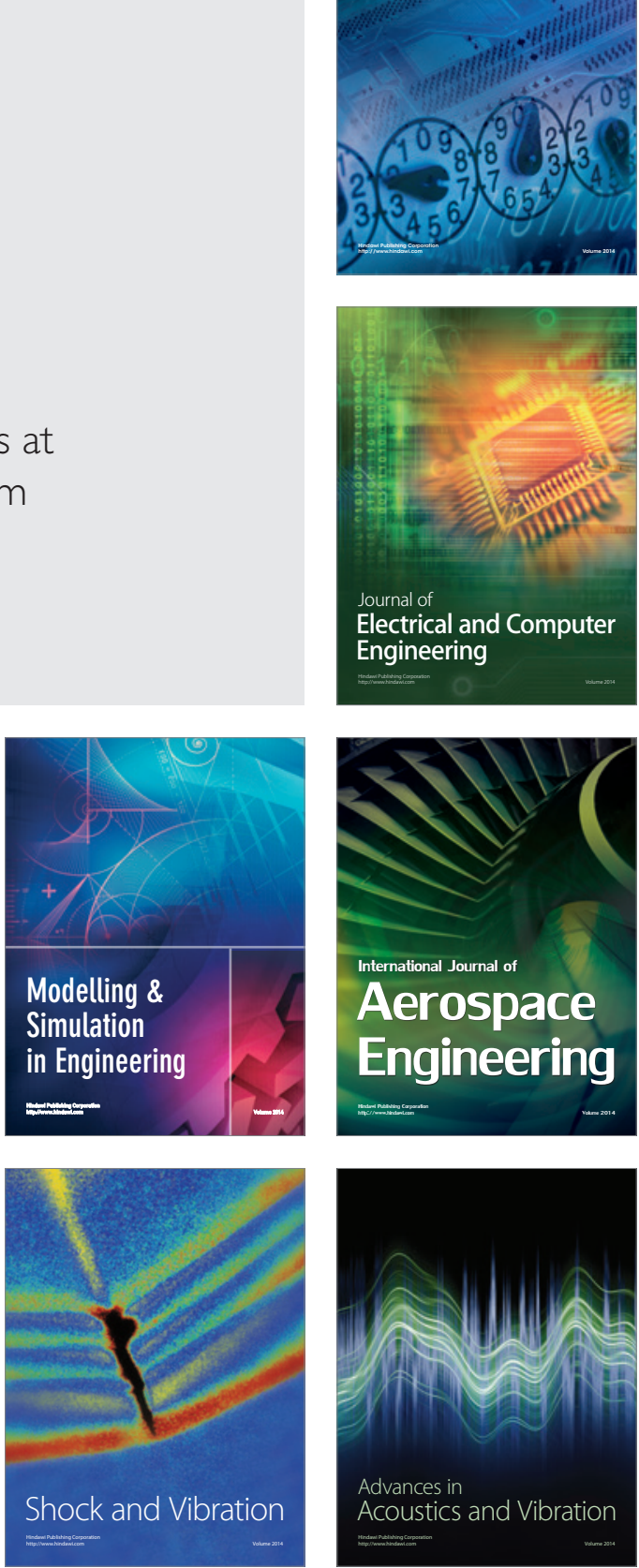